\title{
The characteristics to consider in municipal shared spaces
}

\author{
Brinkoe, Rikke; Nielsen, Susanne Balslev
}

Published in:

Journal of Facilities Management

Link to article, DOI:

10.1108/JFM-11-2016-0051

Publication date:

2017

Document Version

Peer reviewed version

Link back to DTU Orbit

Citation (APA):

Brinkoe, R., \& Nielsen, S. B. (2017). The characteristics to consider in municipal shared spaces. Journal of Facilities Management, 15(4), 335-351. https://doi.org/10.1108/JFM-11-2016-0051

\section{General rights}

Copyright and moral rights for the publications made accessible in the public portal are retained by the authors and/or other copyright owners and it is a condition of accessing publications that users recognise and abide by the legal requirements associated with these rights.

- Users may download and print one copy of any publication from the public portal for the purpose of private study or research.

- You may not further distribute the material or use it for any profit-making activity or commercial gain

- You may freely distribute the URL identifying the publication in the public portal

If you believe that this document breaches copyright please contact us providing details, and we will remove access to the work immediately and investigate your claim. 


\title{
The characteristics to consider in municipal shared spaces
}

\author{
Rikke Brinkø \\ The Technical University of Denmark, DTU, Management Engineering \\ rikbk@dtu.dk \\ Susanne Balslev Nielsen \\ The Technical University of Denmark, DTU, Management Engineering \\ sbni@dtu.dk
}

\begin{abstract}
Purpose

The purpose of this study is through collaboration with practitioners to identify key characteristics of municipal shared spaces and based on these developing a guide for establishing a shared space in a municipal real-estate portfolio.

Design/methodology/approach

This paper builds on existing theory on the subject of shared space as well as the practical experience of professionals within the fields of property management, space management and facilities management. The guide presented is the result of data collected through case studies, interviews, surveys and literature reviews. This knowledge is combined with data collected through a workshop with practitioners from municipalities and the private sector, in order to provide a final guide that is directly applicable as a tool for working with shared space as a part of a property management strategy.
\end{abstract}

\section{Findings}

The result presented is a guide to establishing a shared space in a municipal real-estate portfolio, created in collaboration between researchers and practitioners. It provides an introduction to the topic and outlines a number of tasks that must be completed in different parts of a project, thereby providing a tool which practitioners can use to realise shared space as a strategy in the context of public real-estate management.

Originality/value

The guide presented is a first in connecting theory with practical application and through collaboration between researchers and practitioners creating a tool to be used when working with shared space in a municipal realestate portfolio.

Keywords: Co-creation, facilities management, property management, public real-estate, shared space, space management 


\section{INTRODUCTION}

With global development continuing to move towards cities being the preferred place to live, the capacity of cities all over the world is being pushed to the limits (The World Bank, 2012). In many larger cities space is becoming scarcer and more expensive, with the opposite happening in smaller more rural areas where buildings are standing empty and abandoned. No matter the situation, the traditional way of organising use and many other aspects of city life must be reconsidered, and new business concepts are popping up at a rapid rate. Accommodation can be found via 'Airbnb', transport through 'Uber', services through 'Upwork', working space at coworking offices and the list goes on. Some of these businesses and concepts that started out not so many years ago as small independent initiatives, such as 'Airbnb', has now reached a point where they are surpassing the established industry (Penn \& Wibhey, 2015).

These new challenges and possibilities not only apply for the private sector but also for municipalities. More people moving to cities means an increased population that needs a myriad of different facilities, and spaces to accommodate these functions in order to make city-life work. The result is an increased pressure on the physical infrastructure and facilities that are typically provided by municipalities such as day care institutions, schools, sports facilities, health care facilities, cultural facilities and workspaces for an increasing number of civil servants. With the growth usually comes a need for extra space, while resources do not always allow for this. The sharing of space between different individuals, groups or organisations can be a method to solve some of the problems experienced by cities world-wide (Gaffikin, Mceldowney, \& Sterrett, 2010; Talen, 2006; Williams, 2005). Think of different schools sharing the same sports facilities; day care institutions share the same outdoor space as an elderly home; civil servants of different departments sharing the same office space. In such examples lies the potential of making more efficient use of resources, from both a sustainability-, economic- and social point of view (Walsh, 2011).

Earlier research on shared space (Botsman \& Rogers, 2010; Brinkø \& Nielsen, 2016; Nielsen \& Brinkø, 2016), however, also showed that there can be a number of barriers and unknowns involved making the establishment of a shared space difficult. This is the problem this paper is attempting to tackle by building on theory within the topic of shared space combined with knowledge and experience from practitioners working within the field of property management from both the private industry as well as municipalities. The result of this collaboration is a guide co-created by researchers and practitioners, presenting a method for how to work with shared space in a municipal real-estate portfolio.

\section{THEORY}

\section{Shared space}

Shared space is a unifying term for organising the use of many different types of spaces, with the one thing in common that the space or facility in question is shared between at least two different individuals, groups or organisations. Shared space as field of study has been receiving increasing attention over the last decade or. so with publications covering topics from 'the new office' to the first broad typology of shared space (Duffy \& Powell, 1997; Rafferty, 2012). Moving outside the office, studies on how flexible interior and a focus on adaptable buildings can help increase the possible users over time (Barbosa, Araújo, Mateus, \& Bragança, 2016) are also emerging, as are some of the fist evaluations of shared space. This literature not only illustrates the potential benefits of shared space but also reveals some of the difficulties connected with the concept (Fawcett, 2009; Khajehzadeh \& Vale, 2016; Moss, Ruzinskaite, \& Alexander, 2009; Pitt \& Bennet, 2008; Rafferty, 2012; Uzairiah, Tobi, Amaratunga, \& Noor, 2013). 
The reasons behind the sharing of space can vary widely as can how the sharing is organised, but looking beyond these initial differences the diverse types of shared spaces also have many things in common, especially when looking from an organisational point of view.

(Brinkø, Nielsen, \& Meel, 2015) presents a typology of shared use of space and facilities outlining 4 main types of shared space and describes their individual characteristics using the questions who, what, when and why, meaning who is sharing, what are they sharing, when is the sharing taking place and last but not least, why is the sharing taking place and what is the motivation.

Based on further studies of shared space, and the application of the typology to relevant FM professionals it was found that this typology require quite a bit of introduction to be used as intended, and does not include the aspect of sharing core vs support facilities; an aspect that during additional research has been found to be of key importance. With this in mind the original typology of shared use of facilities by (Brinkø et al., 2015) has been developed in to a version 2.0, see figure 1, as a part of the work presented in this paper.

\section{Typology of shared use of facilities version 2.0}

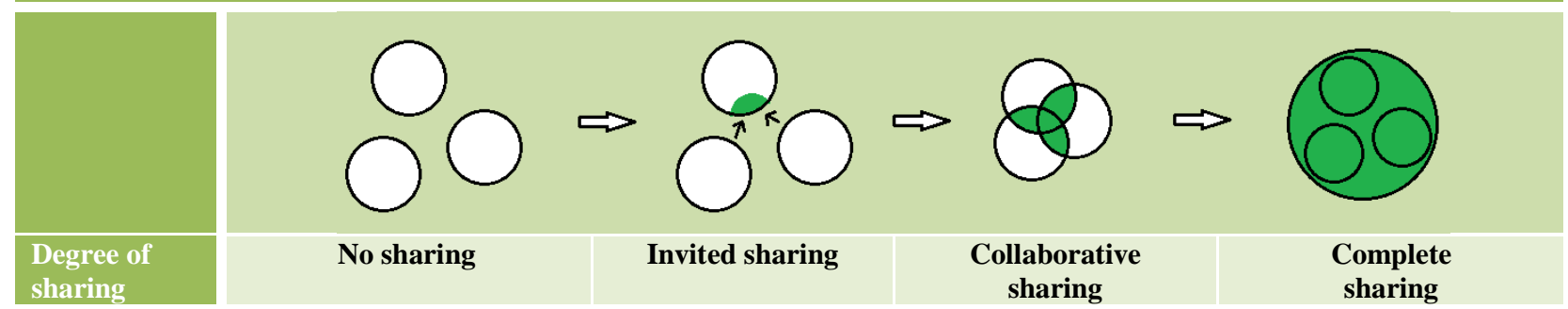

Characteristics of shared space

\begin{tabular}{|c|c|}
\hline What & $\begin{array}{l}\text { Core facilities; } \\
\text { Support facilities; }\end{array}$ \\
\hline When & $\begin{array}{l}\text { Simultaneous sharing; } \\
\text { Serial sharing; }\end{array}$ \\
\hline Why & $\begin{array}{l}\text { Optimising use of m2; } \\
\text { Keep costs down; } \\
\text { CSR activity; } \\
\text { Synergy; }\end{array}$ \\
\hline \multirow[b]{2}{*}{ How } & $\begin{array}{l}\text { Unlimited access; } \\
\text { Access available for employees of the sharing partners; } \\
\text { Access restricted to individuals/groups approved by owner; }\end{array}$ \\
\hline & $\begin{array}{l}\text { One party has ownership and makes the space available either free or for a fee; } \\
\text { Different owners come together and agree on sharing specific facilities or locations with each other; } \\
\text { A third party has ownership and manages the space for the parties sharing; }\end{array}$ \\
\hline \multirow[t]{3}{*}{ Themes } & Practicalities: \\
\hline & Involvement \\
\hline & Territoriality \\
\hline
\end{tabular}

Figure 1: The typology of shared use of facilities v2.0

The typology has been simplified with three levels of sharing, and still presents a common language and understanding of what shared space is in the context of the built environment, but the categories, or types, are now based on the degree of sharing taking place from 'no sharing', to 'invited sharing', 'collaborative sharing' and last 'complete sharing'. The typology still represents maximum diversity and variation of shared 
spaces, now condensed to three main levels, and is as the original organised by scale, with the least comprehensive shared space to the left and increasing complecxity towards the right.

The descriminators what, when, why, who and how used in the original typology are still a key aspect of the new typology, but are now held in a separate table in connection with the new levels, and are meant to 'be used to describe a specific shared space and not as a description of a type. The new version of the typology also incorporate another new aspect developed by (Brinkø \& Nielsen). Building on the understanding of the original typology of shared use of facilities, (Brinkø \& Nielsen) conducted additional studies, and presents three themes to be managed independently of what type, or level, of sharing is being addressed namely, territoriality, involvement and practicalities, as illustrated in table 1.

\begin{tabular}{|l|l|l|l|}
\hline Statements & Territoriality & Involvement & Practicalities \\
& Personality & Influence & Planning \& availability \\
& Identity & Information & Information \\
& Control & Being taken seriously & Access \& security
\end{tabular}

Table 1: Three themes to be managed (Brinkø \& Nielsen, n.d.)

According to (Brinkø \& Nielsen), these themes are essential to consider when working with shared spaces whether the shared space in question is a new one under development or an already well-estbablished existing one. How they should be managed depend on the specific shared space in question, since the extent to which they arise is depended on a number of characteristics of the shared space, such as extent of sharing, forced or voluntary sharing, sharing of core or support space etc. The themes were developed based on the original typology of shared space, but have been incorporated in the new version 2.0 presented in this paper.

The new typology with the three themes incorporated illustrated in figure 1 will in this paper be used as the theoretical framework for describing shared space, and to guide the discussion and development of the practical guide presented, in order to secure that the relevant information and factors are included in the final result.

\section{Public real-estate}

The management of property and real-estate in general, is a field that in short deals with the management of buildings on a strategic level. It encompasses the operation, control and oversight of real-estate in the broadest term of the word, and the real estate process can be described as the constant interaction of three groups; space users (consumers), space producers (those with site specific expertise) and public infrastructures (offsite services and facilities) (Graaskamp, 1992). Within this overall field of real-estate management lays the more specific management of public real-estate, which constitutes the context for the work presented in this paper.

Public real-estate management is different from private, or corporate, real-estate management in a number of ways. "Public real estate portfolios have very specific characteristics and there is clear evidence of political influence on the quality and location of the buildings included in them. This, in turn, has a strong effect on how such properties are managed." (van der Schaaf, 2002). It is a discipline of growing significance for local government across the world (Phelps, 2011), and in many countries municipalities not only own but manage large real-estate portfolios in order to provide the necessary services for the population and community, such as public buildings, infrastructure, schools, hospitals, social housing etc., and also buildings necessary for carrying out the administrative functions connected with municipal obligations (Klumbyte \& Apanaviciene, 2015). 
In connection with the topic of this paper, the focus within public real-estate and real-estate management is mainly in relation to a municipality's objectives in working with real-estate management, meaning motivations, and secondly in relation to where a development towards shared space could or should take place. In this regard much can be learned from existing literature.

According to (Trojanek, 2015) the main objective of managing real estate owned by a municipality is to effectively use municipal real estate in the process of performing public tasks such as meeting collective needs of the community by providing local public goods. Within this overall purpose (Trojanek, 2015) also lists a number of different objectives of managing the public real estate, depending on the functions performed by the real estate. Municipal real estate may serve to:

- implement the municipality's statutory obligations (functions of an administrative and public utility character)

- generate one-off or periodical revenue streams (sales), e.g. rent, lease, lending

- implement investment projects or build up a reserve for the implementation of development objectives in the future

Moving to identifying potential on a portfolio level, (Dowall, 2007) presents an evaluation system that should be set up as a series of "screens" that a site must filter through before it is considered for development resulting in the following three 'classes' of sites.

1. Vacant, potentially developable sites not required for public use;

2. Under-utilized sites with potential for intensified development; and

3. Fully developed sites with no potential for further development.

According to (Myers \& Wyatt, 2004) there is a need to identify and create a more efficient use (and reuse) of existing real estate, a need shared space potentially can assist in addressing. In connection with this an understanding of the mechanisms involved and where the greatest potential lies is key in implementing the use of shared space in a municipal real-estate portfolio. Considering the large amount of real-estate owned and management by public entities and municipalities means that public property management comes with a large potential when looking at the possible impact of shared space as a method for space optimisation. It is the realisation of this potential the guide presented in this paper is developed to assist.

\section{Workplace and space management}

Despite the fact that the focus of this paper is not on workplaces as such, but a more general rethinking of the single-user or single-function approach to buildings, much can still be learned on the mechanisms involved in managing change and transformation from existing literature.

Over the last couple of decades an increasing amount of literature has been published on the topic of shared space in the workplace, with (Duffy \& Powell, 1997) describing “The new office”, (Khamkanya \& Sloan, 2009) writing on flexible working and shared workspace and (Luck, 2015) writing on co-location for design work. Following from the space management approach, agile working and the field of workplace management provides insights in to how to manage an organisational change such as transitioning to shared space must be considered to be (Bell \& Anderson, 1999). The importance of providing physical solutions that meet the definition of 'agile' (easily adaptable, flexible, and varied) environments; a key component in shared space, is another topic touched upon by (Bell \& Anderson, 1999). (Hewitt, 1997) describes 'the city workplace'; an experiment and test to demonstrate how different space could be used in numerous ways to support a multitude of tasks; another key component in shared space. 


\section{METHODOLOGY}

In order to translate the theoretical knowledge on shared space developed via research to a practical tool to be used by municipalities, a workshop was chosen as the framework for collaborative development of a guide to establishing a shared space. This guide is a culmination of three years study of shared space, and is the result of a large number of case studies and interviews, culminating in a workshop with practitioners, in order to connect the theoretical findings with knowledge and experience from the industry. The product of which is a guide that can be applied and utilised in practice when working with shared space in a municipal real-estate portfolio. The overall research approach is illustrated in figure 2.

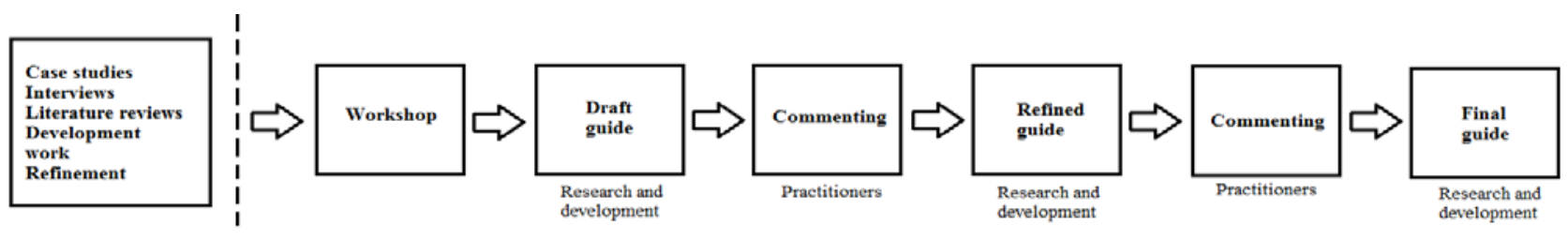

Figure 2: Research approach

As can be seen in the figure, the development process is that of a continuous cycle of feedback and improvement following the initial workshop. This method has been chosen in order to secure that the product developed was of a format and content that was easily implemented in the work of the practitioners, while still encompassing all the different aspects of shared space that has been identified through literature and empirical studies. An in-depth account of the workshop, both as a method and how it was conducted in this particularly case, will be given in the following.

\section{Workshop}

A workshop, similar to the focus groups described in (Saunders, Lewis, \& Thornhill, 2016), can be used to acquire more in-depth knowledge about the participants views on a specific topic by "encouraging interactions between participants as an effective means to articulate pre-held views" (Saunders et al., 2016). This makes it very well suited for the purpose of this study - to create a guide for practitioners by practitioners. Facilitation of the workshop was conducting with inspiration from the work of (Ravn, 2014).

The participants invited to the workshop come from a variety of professions. The municipalities of LyngbyTaarbæk and Copenhagen were represented by multiple participants due the study's focus on municipal realestate. In addition to these a number of professionals from the private sector, with previous knowledge and experience from working with shared spaces in practice, were invited to provide valuable input from practical applications. A total of 15 participants attended the workshop, 8 from the two municipalities and an additional 7 from various companies from the private sector; among which were architects, consults and an owner of a successful shared space in Copenhagen, see table 2. An additional 4 had signed up for the workshop but were unable to attend for different last minute reasons, but were still involved in the processing and feedback loop taking place in the period after the workshop.

\begin{tabular}{l} 
Workshop participants \\
\hline Lyngby-Taarbak \\
Lyngby-Taarbak \\
Lyngby-Taarbak \\
Lyngby-Taarbak \\
Lyngby-Taarbak \\
Copenhagen \\
Copenhagen
\end{tabular}

\section{Representative}

Director, properties

Development consultant, properties

Property operations manager

Head of Department, secretariat

Development consultant

Operations manager, properties

Development consultant

\section{Experience within:}

Planning, development, real-estate management Planning, development, real-estate management Planning, development, real-estate management Planning, development, real-estate management Planning, development, real-estate management Planning, development, real-estate management Planning, development, real-estate management 


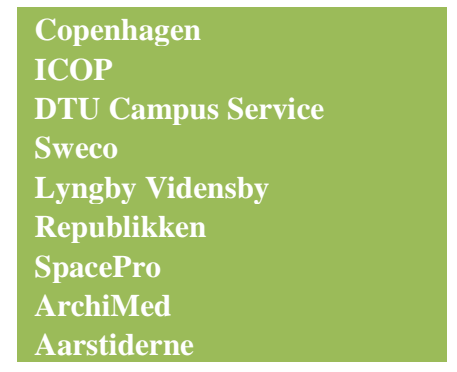

Project manager, properties

Director

Section Manager

Chief Advisor

Director

Director

Director

Director

Project manager
Planning, development, real-estate management

Planning and designing office space

Planning, designing and managing university space

Space and construction management

Network management, creative environments

Managing a cowork space

Planning and designing space and buildings

Planning and designing shared space

Planning and designing shared space

Table 2: Workshop participants

These particular participants were invited based on the criteria of having had previous practical knowledge with shared space, and therefore being able to contribute with hands-on experience about the process.

The workshop itself was organised with a theoretical introduction to the subject at hand, shared space, and a presentation of the theoretical findings produced during the study so far. After this introduction the first task was introduced and the participants were divided in to two groups for the first group work session, focusing on screening for shared space in a municipal real-estate portfolio. After completion a representative from Lyngby-Taarbæk municipality presented a real-life ongoing case from the municipality for inspiration, and the second group work session was initiated, focusing on the steps necessary when creating a specific shared space at a chosen location. For both sessions an initial framework was introduced to keep the discussions centred on topics relevant for the guide and to ensure sufficient depth and usability of the result. The framework was centred on a short content description to steer the discussion and a connected question and task of coming up with 7 steps to complete the work proposed.

The choice of 7 steps was made to secure sufficient detail of the steps proposed while still keeping it manageable within the timeframe given, and was worked with as a guideline and not a strict requirement. Intervention by the facilitators only took place when groups approach for clarification of a question, or if it was clear that the discussions taking place were drifting off subject. The groups were asked to write their suggestions on posters which after both the group-work sessions were completed were presented by a representative from each group followed by a general discussion of the results among all participants, marking the end of the workshop.

\section{Development of the guide}

Following the end of the workshop all posters and notes collected during the event was collected and brought back for processing. The method of developing the information in to a guide consisted of the following steps:

1. Write up all steps proposed from all groups and take out steps repeated.

2. Sort the steps into three categories related to either users, buildings or organisation

3. Send this first documentation of the steps created during the workshop out to workshop participants for feedback

4. Further develop this initial draft based on previous knowledge on shared space; adding steps missing from the original draft and formulating all in a more precise way to minimize misunderstandings and optimise content, as well as adding an introductory text describing the topic and a number of different aspects involved in working with shared space

5. Send this second version out to workshop participants for feedback

6. Further develop the content created to a final draft version

7. Send this final version out to workshop participants for final commenting and approval

8. Finalise guide 
The considerations for this part have mainly been on converting the data collected at the workshop in to a manageable list of steps to be taken, without losing important meaning or information in the process. Some suggestions made at the workshop were so close to one another that they have been merged in the final figure and others that contained too much information have been divided in to more steps. Lastly, knowledge obtained from additional studies, not already contained in the steps, were added to complete the guide to establishing a shared space in a municipal context. The final guide resulting from this work will be presented in the following.

\section{RESULTS}

The result presented in this paper is as mentioned a guide to identifying potential locations for shared spaces as well as establishing one when a location has been chosen, and it is developed within the context of municipal real-estate management. The guide is made up of two main parts;

Part 1) The purpose with this part of the guide is to provide a general understanding of what it is involved before starting to work with shared space in order to ensure the right mind-set. The information contained in this section has been collected through previous studies of shared space, containing knowledge from both literature reviews and theoretical studies of existing shared spaces, as well as empirical data collected through in-depth case studies, interviews etc., and contains the following elements:

a. An introduction to shared space

b. An introduction to identifying potential for shared space

c. A number of practical considerations to be managed when working with shared space

d. An introduction to the challenges to be managed when working with shared space

Part 2) The second part of the guide contains a step-by-step approach to establishing a shared space, and is divided in two overall parts; the first containing an introduction to the four different elements of the guide beginning with the portfolio level and ending with post project evaluations. The second part of this section is a one-page figure containing a number of steps within each element that must be considered. It is the most tangible part of the guide, and contains recommendations from practitioners to practitioners. The elements are:
a. Portfolio analysis
b. Pre-project
c. Project
d. Post-project

These are followed by a figure illustrating the steps to be taken within each element

\section{Part 1a; introduction to shared space}

This first section contains the general introduction to shared space, followed by a list of 5 possible benefits of working with shared space, with a short description of each to motivate and inspire shared space initiatives in a municipal building portfolio. The explanatory text introduces shared spaces as a collective term for space and facilities shared between people from organisational contexts, and how it can lead to a number of positive aspects for the stakeholder involved. The text also introduced a societal perspective, where shared space has the potential to create more vibrant and attractive urban environments which can stimulate cultural and economic innovation, by attracting more and different types of users to an area. So there are several different motivations that may lie behind the decision to establish a shared space, and the 5 examples listed in the guide are: 
- Optimised use of square meter: Optimised use of fewer facilities and buildings will allow for fewer buildings total in the portfolio, and will therefore be able to contribute to an overall area optimisation

- Cost reduction: Optimized use of fewer facilities and buildings will mean fewer buildings to be maintained and operated, allowing for a release of funds to be used elsewhere

- Synergies: If the focus in addition to space optimisation and reduction of costs also is on gathering users who could benefit from each other, it is possible to create a situation that allows for synergies to develop between the users and thereby achieve an additional benefit of shared use.

- Sustainability: Intensified use has on an overall level has the potential to contribute to increased sustainability in the building stock. If multiple users are moved to one building instead of several buildings are left empty much of the time, but still have to be maintained and operated, it can have a positive effect on the overall sustainability, despite the increased use resulting in a greater load on the specific building.

- Flexibility in the portfolio: The possibility of, for example, launching a new initiative in an existing building or room provides the opportunity to assess the viability of the initiative before a permanent space is assigned, which represents one of the ways in which shared space can contribute to flexibility in a portfolio.

\section{Part 1b; introduction to identifying potential for shared space}

This section provides a short introduction to identifying potential for shared space on a portfolio level, followed by three suggestions for possible user-types or functionalities that could be co-located in shared spaces in a municipal context to serve as inspiration. The text starts by introducing two different approaches to identifying users that will be able to interact successfully in shared space. The first is identifying users in need of the same type of building, premises or facility, either at different times of the day or the same time if the amount and type of use permits this. The second approach is to identify different types of users who will be able to complement each other in their use of a given building, room or facility. This illustrates the importance of considering the functional overlap / match between different functions, user groups and organisations before selecting a location for a shared space. The three examples listed in the guide are:

- Co-location of schools youth clubs and after school activities, as the functional requirements of these buildings and facilities is comparable, used by the same group of users but at different times of the day.

- Co-location of offices and / or administration buildings for different departments or groups

- Co-location of functions such as libraries, community centres and other 'open' functions serving the local area

\section{Part 1c; practical considerations to be managed when working with shared space}

This section contains very little introductory text, and is mainly constituted by a list of practical considerations that must be managed when working with shared space, and the 5 examples listed are:

- Time of use: Should the sharing take place simultaneously or in succession, and should the sharing be equal or should one or more users have "priority rights"? 
- Security / Access: If the sharing is not available to all, but only pre-approved groups or individuals, how then should the access control be managed? ID cards, keys, passwords etc.? Furthermore, if a building for example, must be available to certain users at odd times of the day, how should the security be handled?

- Differences in functions and needs: If the different users of a space have different needs in relation to, for example, interior and storage how should this be handled?

- Legislation: If a building needs to be shared by for example a school and a day-care, there will be different regulatory requirements in relation to the two user groups which must be considered in the planning and design of the buildings and premises. A similarly dilemma could also arise if the sharing is taking place between a public and a private party and is important to consider in the planning.

- Cleaning and maintenance: When you have many different users of a building, room or facility, there is always a chance that 'everyone's room is nobody's responsibility'. Who is responsible if something breaks? Who is responsible for cleaning? What to do if the space is a mess when you arrive? etc. etc. etc. These are aspects of shared space that are necessary to have a plan for in advance.

\section{Part 1d; introduction to the challenges to be managed when working with shared space}

The last section introduces three main challenges to be managed when working with shared spaces, territoriality, involvement and practicalities, described by (Brinkø \& Nielsen, 2016). The bullet points in the guide describe these three themes in more detail, and provide some information on why they occur and how they can be taken into account in the planning and construction process.

- Territoriality: Territoriality deals with the emotions and reactions that arise when transitioning from a situation of having one's own space to a situation with shared space, and the consequent loss of control following this transition. Several factors affect the degree of territoriality that will occur, and thus also the amount of time and energy that should be allocated to deal with it. Above all territoriality depends on the degree of sharing taking place; the more you have to share, the more likely it is for territoriality to occur, and the more important it will be to have a plan for how to cope with it. In addition to this, a pre-existing relationship with the other parties participating in the sharing plays a big role; the better you know the other parties the easier the transition to shared space will be. Last but not least, the location plays a role. The longer time spent at a given location, the stronger the feelings of territoriality are likely to be, and the more important it will be to address them.

- Involvement: Following the issue of territoriality, there is the matter of user involvement. As described above, there is a big difference between sharing with people you know and people you do not know, and in addition to this there is a significant difference between being "forced" to share and to be "participatory" in the decision to share. Engaging the individuals or groups having to change habits from having their own to having to share, can contribute to a greater understanding of each other, something which will have a positive effect in itself, but it can also create a feeling of having a say in the matter even if you have not had influence on the decision itself. There are countless ways in which users can be involved in the process, and the key is to identify which of these methods is best suited to a given situation and a given purpose, depending on the type of input and collaboration that is desired. 
- Practicalities: There are a large number of practical aspects to be considered when working with shared space. Unlike traditional use, shared space involves multiple users from several different organisations, each with their administration, financial situation, etc. A large part of these practical considerations are discussed in the previous section and will therefore not be described in depth here, but there are a few additions. There are basic logistics in relation to all aspects of ensuring that a building and its users function as optimal as possible. It is relevant in the project phase where the focus will be on the logistics of handling inventory and users in a possible transition phase, offering alternatives during renovations, providing information about the project and the process. It will be relevant in relation to providing booking systems, planning availability and use, maintenance, etc., when the room or the building is in use. There are considerations about cleaning, maintenance, administration, security, access, etc., and all these must be met in order to get from idea to realisation.

\section{Part 2a-d; shared space step by step}

These sections contain the introduction to the four different overall elements contained in the step-by-step figure following. The purpose with this is to create an overview and understanding of the elements that make up the establishment of a shared space from identifying potential to finished project, in order to secure that all elements in the process receive the necessary attention. The elements described are:

- Portfolio level: The first step in the process concerns the identification of potential locations for shared space at the portfolio level. For this step to be performed, it is necessary to collect a quite a bit of information concerning each building in the portfolio, and if the information is already present, it is necessary to make sure that it is up to date. The purpose of this is to create an overview of the property available, where they are located and in what condition they are in, after which a decision on which locations have a potential for shared space can be made on an informed basis. The overall focus is thus on collecting general knowledge of the buildings in a given portfolio, and on what information is needed in order to identify potential for shared space.

- Pre-project: In this next step in the process, the decision to develop a shared space in a specific building or group of buildings has been made, and the pro-project can begin, meaning the phase in the process where the framework for a specific project is decided. The purpose of this part of the process is to prepare a detailed description of the framework for the project by performing an indepth study of the needs of users, buildings and organization to ensure an optimal situation for the transition to shared space. The overall focus is therefore on describing the basic project framework and to ensure a clear objective before establishing a shared space

- Project: After the basic framework of the project is decided, the next part of the process begins; the main project. This is where the transition to shared space is realised, and the overall focus is therefore on what activities are needed to ensure that the planned project is being implemented in a satisfactory manner

- Post-project: After completion of the main project and the shared space is realised, there still lies a task in evaluating if the purpose of the project and the desired outcome have been achieved as intended. The focus of this part of the process is to evaluate the measures undertaken and to examine whether the final shared space live up to expectations formulated for the project. Furthermore, it is also important in this phase to evaluate the lessons learned along the way so these can be incorpo- 
rated in future projects in order to further optimise the process. The overall focus of this part is therefore on the stage after the project is completed, and on how to ensure that the intended use is realized and maintained.

The next part is the figure containing the necessary steps to be taken throughout the process, and this can be seen in the following.

Continuous focus on anchoring and communication at the political level

\begin{tabular}{|c|c|}
\hline & Portfolio analysis \\
\hline Users & Buildings \\
\hline $\begin{array}{l}\text { Who are the users? } \\
\text { Perform requirement analysis - overall } \\
\text { level } \\
\text { Perform stakeholder analysis - overall } \\
\text { level } \\
\text { Obtain relevant working environmental } \\
\text { data }\end{array}$ & $\begin{array}{l}\text { Which buildings do we have and what is the condition? } \\
\text { Develop a plan for FM platform and data collection } \\
\text { Examine demographics and location } \\
\text { Map m2 } \\
\text { Perform building inspection if necessary } \\
\text { Examine operating costs and property values } \\
\text { Examine suitability in relation to current use } \\
\text { Examine flexibility, needs for modernisation \& } \\
\text { degree of utilisation }\end{array}$ \\
\hline
\end{tabular}

Identify the location for the creation of shared space

\begin{tabular}{|c|c|c|}
\hline \multicolumn{3}{|c|}{ Pre-project } \\
\hline Users & Buildings & Organisation \\
\hline $\begin{array}{l}\text { Who are the users and what is their need? } \\
\text { Perform requirement analysis - user level } \\
\text { Perform stakeholder analysis - user level } \\
\text { Define clear terms. What is fixed and what } \\
\text { can the users influence } \\
\text { Identify key people / ambassadors who can } \\
\text { follow the project from start to finish } \\
\text { Map existing features, environment \& culture } \\
\text { Communicate what is expected to be shared } \\
\text { vs own m2 } \\
\text { Investigate what can be changed and what } \\
\text { must be respected and maintained }\end{array}$ & $\begin{array}{l}\text { What, and how much, work must be done? } \\
\text { Map number of } \mathrm{m} 2 \text { involved. What } \\
\text { should be shared, what is 'own' and } \\
\text { what is potential new } \\
\text { Perform analysis of the immediate } \\
\text { area. Proximity to public transportation } \\
\text { and the like. }\end{array}$ & $\begin{array}{l}\text { How should the organisation and administration be } \\
\text { done? } \\
\text { Appoint steering committee / project organization } \\
\text { Identify the purpose of the project } \\
\text { Set frames } \\
\text { Formulate communication strategy } \\
\text { Define responsibilities } \\
\text { Formulate realistic project proposal / scenarios } \\
\text { Initiate political involvement and decision-making } \\
\text { Initiate authority process } \\
\text { Perform quality assurance of the financial } \\
\text { framework (buying, selling, renting) } \\
\text { Initiate interdisciplinary administrative work } \\
\text { Initiate consultative process }\end{array}$ \\
\hline
\end{tabular}

Develop the business case / project description for the project

\begin{tabular}{|c|c|c|}
\hline \multicolumn{3}{|c|}{ Project } \\
\hline Users & Buildings & Organisation \\
\hline $\begin{array}{l}\text { How should the users be involved and informed? } \\
\text { Define a clear vision and core values } \\
\text { Perform user involvement via workshops, } \\
\text { open public meetings etc. } \\
\text { Focus on ensuring users' feeling of ownership } \\
\text { of the buildings } \\
\text { Ensure frequent communication and only } \\
\text { promise what is sure to be kept } \\
\text { Use concrete proposals, and show examples } \\
\text { of previous successes } \\
\text { Celebrate milestones } \\
\text { Establish a response function }\end{array}$ & $\begin{array}{l}\text { What should be shared and what should be } \\
\text { private? } \\
\text { Formulate clear guidelines for the use of the } \\
\text { building } \\
\text { Design and decorate the building so that it } \\
\text { supports shared use } \\
\text { Include flexibility in the design }\end{array}$ & $\begin{array}{l}\text { How should the project be realised and } \\
\text { managed? } \\
\text { Formulate an effective project schedule } \\
\text { Plan the administration of the building } \\
\text { Plan implementation of the project to the } \\
\text { operating team }\end{array}$ \\
\hline
\end{tabular}




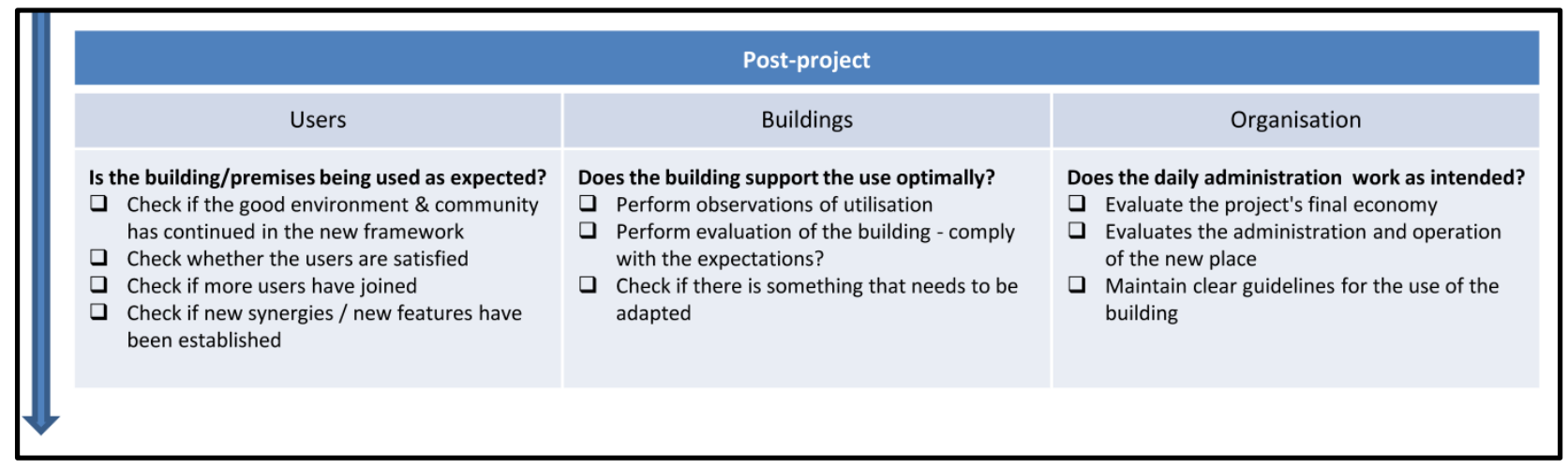

Figure 3: Main figure of the guide containing the steps from each element in the process

\section{DISCUSSION AND CONCLUSION}

The result presented in this paper is a guide to identifying potential locations for shared spaces as well as establishing one when a location has been chosen, and it is directed towards municipalities. The information contained in the guide has two main sources; the introductory texts consists mainly of information from previous studies on shared spaces, and the information contained in figure 3 consists mainly of information collected through a workshop with practitioners, as described in the methodology section.

The two main results from the workshop and subsequent development of the guide revolve around first of all a number of aspects to search for when trying to identify buildings or spaces where there could be a potential for establishing a shared space, and second on how to implement the change to shared space once a site has been selected. Beginning with identification for potential, the factors identified during the workshop are:

Identification of potential for shared space:

- Flexibility of the building or space in question

- Closeness to public transport

- General infrastructure in the area

- Capacity of the building or space in question

- Condition of the building or space in question (basic technical installations, building envelope, structural components, interior, modernisation needs)

- Regulatory requirements (existing contracts, existing tenants)

- Existing use of the building or space in question (type of building, type of activities)

- Financial situation (value of property, running and maintenance costs)

- Whether the municipality had other buildings or addresses in the area, either owned or leased

As described in the theory section (Dowall, 2007) and (Trojanek, 2015), among others, have presented work relevant for the motivation for public real-estate management and for screening for potential in relation to identifying potential sites re-development. The results presented in these papers support the findings from the workshop mentioned above.

Moving on to implementation of shared space, the factors identified and presented in the guide revolve around the following topics:

- Involve the future users and communicate continuously

- Consider the functional overlap of the people/groups who will be using the space 
- Secure sufficient flexibility in the space so it can support the multiple users

- Consider the themes territoriality, involvement and practicalities

The themes of territoriality and involvement of uses are well-described phenomenons in literature and have been thoroughly researched in some of the work this paper builds on (Brinkø \& Nielsen, 2015, 2016), and also presented in the theory section of this paper. As also mentioned in the theory section, the aspects of flexible working and agile workspaces, which are important elements in shared space and one of the key elements from the workshop, are described by a number of authors such as (Luck, 2015), (Bell \& Anderson, 1999) and (Hewitt, 1997), not to mention the many guides on designing open space offices from for example (Duffy, Craig, \& Gillen, 2011) and many others.

The guide presented in this paper draws not only on available literature but incorporates the practical knowledge and experience of practitioners and defines a number of more detailed steps that can be taken in practice, developing on the existing knowledge in the area and translating it to a practical tool to be used municipalities. Yet, it is clear that the developed guide is just a guide-it is no magic recipe for success. One of the important messages of the workshops was that real estate decisions in the public sector are complex matters in which politics, power relations and the personal attitude of the people involved play a large role. In every day practice, the success and possibilities of sharing facilities are strongly dependent on the willingness and capabilities involved. A guide can help the involved stakeholders to get acknowledged with the concept and help them to plan the steps to take, but such projects will probably also need some 'pushing and shoving' or 'selling' to get all stakeholders on board.

\section{LIMITATIONS AND APPLICABILITY TO GENERALISATION}

In relation to practice there are a number of limitations connected with the guide. First of all it is important to note that the result presented is meant as a guideline, and all information will not be equally relevant for all shared space development projects. Furthermore it represents an idealised process, and during a real-life project some steps will most likely overlap while others will be the centre of either more or less focus than described in the guide, and there will also be the risk of the political establishment overruling the process.

Also; the guide has not yet been tested in practice, but based on the feedback from the workshop's participants we believe that the guide can make a practical contribution to the implementation of space sharing practices in municipal organizations. For ourselves, it is an important step in which we try to translate the insights of our research work to practical recommendations. This is not the purpose of research per se, but the field of space- and property management is inherently practical and we think that it is important for researchers to reach out to practice. A guide like this is a good example.

Furthermore; the guide as it is presented here is intended for use in a municipal building portfolio, but that does not mean that it is not applicable in the private sector. Public real-estate adds an additional layer of difficulty in the organisation and decision making process, but the main aspects of shared spaces and the use of these spaces will be the same. Equivalently will the themes territoriality, involvement and practicalities be equally relevant whether the organisational framework is private or municipal building portfolio. This means that with a relevant insignificant amount with work adapting the guide developed here; it will be usable within the private sector as well.

\section{REFERENCES}

Barbosa, J. A., Araújo, C., Mateus, R., \& Bragança, L. (2016). Smart interior design of buildings and its relationship to land use. Architectural Engineering and Design Management, 12(2), 97-106. 
http://doi.org/10.1080/17452007.2015.1120187

Bell, S. M., \& Anderson, M. (1999). Workplace solutions. Journal of Corporate Real Estate, 1(4), 349-360. http://doi.org/10.1108/14630019910811132

Botsman, R., \& Rogers, R. (2010). What's mine is yours. HarperCollings publishers.

Brinkø, R., \& Nielsen, S. B. (2015). Shared space in a municipal sports facility - The case of Lyngby Idraetsby. In EuroFM: Advancing Knowledge in Facilities Management: People make Facilities Management.

Brinkø, R., \& Nielsen, S. B. (2016). Shared space: a cross-case analysis. Submitted to Journal of Urban Design.

Brinkø, R., Nielsen, S. B., \& Meel, J. Van. (2015). Access over ownership - a typology of shared space. Facilities.

Dowall, D. E. (2007). The Public Real Estate Development Process, 4363(July 2012), 37-41. http://doi.org/10.1080/01944369008975454

Duffy, F., Craig, D., \& Gillen, N. (2011). Purpose, process, place: design as a research tool. Facilities, 29(3/4), 97-113. http://doi.org/10.1108/02632771111109243

Duffy, F., \& Powell, K. (1997). The new office. Conran Octopus.

Fawcett, W. H. (2009). Optimum capacity of shared accommodation: yield management analysis. Facilities, 27(9/10), 339-356. http://doi.org/10.1108/02632770910969595

Gaffikin, F., Mceldowney, M., \& Sterrett, K. (2010). Creating Shared Public Space in the Contested City: The Role of Urban Design. Journal of Urban Design, 15(4), 493-513. http://doi.org/10.1080/13574809.2010.502338

Graaskamp, J. a. (1992). Fundamentals of Real Estate Development. Journal of Property Valuation and Investment, 10(3), 619-639. http://doi.org/10.1108/14635789210031253

Hewitt, K. (1997). City workplace. THE COMPUTER BULLETIN, (February), 1-2.

Khajehzadeh, I., \& Vale, B. (2016). Shared student residential space: a post occupancy evaluation. Journal of Facilities Management, 14(2), 102-124.

Khamkanya, T., \& Sloan, B. (2009). Flexible working in Scottish local authority property: Moving on to the highest flexibility level. International Journal of Strategic Property Management, 13(1), 37-52. http://doi.org/10.3846/1648-715X.2009.13.37-52

Klumbyte, E., \& Apanaviciene, R. (2015). Real estate strategic management model for Lithuanian municipalities. International Journal of Strategic Property Management, 9179(October). http://doi.org/10.3846/1648715X.2014.942407

Luck, R. (2015). Organising design in the wild: locating multidisciplinarity as a way of working. Architectural Engineering and Design Management, 11(2), 149-162. http://doi.org/10.1080/17452007.2014.892472

Moss, Q. Z., Ruzinskaite, J., \& Alexander, K. (2009). Using buildings for community benefits: A best practice case study with North City Library. Journal of Retail and Leisure Property, 8(2), 91-98. http://doi.org/10.1057/rlp.2009.2 
Myers, D., \& Wyatt, P. (2004). Rethinking urban capacity: identifying and appraising vacant buildings. Building Research and Information, 32(4), 285-292. http://doi.org/10.1080/0961321042000221061

Nielsen, S. B., \& Brinkø, R. (2016). Access over ownership - the case of meetingfacilities in Lyngby Knowledge City. In CIRRE2016, 1st conference of interdisciplinary research on real estate.

Penn, J., \& Wibhey, J. (2015). Uber, Airbnb and consequences of the sharing economy: Research roundup. Journalist's Resource, 1-13. Retrieved from

http://journalistsresource.org/studies/economics/business/airbnb-lyft-uber-bike-share-sharing-economyresearch-roundup?utm_source=twitter

Phelps, A. (2011). Municipal property asset management-a comparative study of UK and Russia. International Journal of Strategic Property Management, 9179(4), 416-437. http://doi.org/10.3846/1648715X.2011.642537

Pitt, M., \& Bennet, J. (2008). Workforce ownership of space in a space sharing environment. Journal of Facilities Management, 6(4), 290-302.

Rafferty, G. (2012). Embracing the Creation of Shared Space : Considering the Potential Intersection between Community Planning and Peace-building. Space and Polity, 16(2), 197-213.

Ravn, I. (2014). Facilitering: Ledelse af møder der skaber væerdi og mening (1. edition). Hans Reitzels forlag.

Saunders, M., Lewis, P., \& Thornhill, A. (2016). Research methods for business students (7th ed.). Pearson.

Talen, E. (2006). Design for Diversity: Evaluating the Context of Socially Mixed Neighbourhoods. Journal of Urban Design (Vol. 11). http://doi.org/10.1080/13574800500490588

The World Bank. (2012). Urban Development. Retrieved November 4, 2016, from http://data.worldbank.org/topic/urban-development

Trojanek, M. (2015). Strategic municipal real estate management. Journal of International Studies, 8(2), 187-196. http://doi.org/10.14254/2071-8330.2015/8-

Uzairiah, S., Tobi, M., Amaratunga, D., \& Noor, N. M. (2013). Social enterprise applications in an urban facilities management setting. Facilities, 31(5).

van der Schaaf, P. (2002). Public Real Estate Management - Challenges for Governments.

Walsh, B. (2011). 10 Ideas That Will Change the World. Time, 1-2. Retrieved from http://www.time.com/time/specials/packages/article/0,28804,2059521_2059717_2059710,00.html

Williams, J. (2005). Designing Neighbourhoods for Social Interaction: The Case of Cohousing. Journal of Urban Design, 10(2), 195-227. http://doi.org/10.1080/13574800500086998 